\title{
Smoke-Free Home Program with Number of Cigarettes in Yogyakarta
}

\author{
Muchsin Maulana $^{1 *}$, Septian Emma Dwi Jatmika ${ }^{1}$, Kuntoro ${ }^{1}$, \\ Santi Martini ${ }^{1}$, Sri Widiarti ${ }^{1}$, Sholikhah Nur Azizah ${ }^{1}$ \\ ${ }^{I}$ Public Health Faculty, Ahmad Dahlan University, Yogyakarta, Indonesia \\ *Corresponding author. E-mail: muchsin.maulana@ikm.uad.ac.id
}

\begin{abstract}
Background: Smoking behaviour is a problems who have lost, not only for health but also for other aspects in the life. The role of the government had not yet can be relied on to send down a prevalence of smoking in Indonesia which annually increased, so that gave rise to the initiative control program cigarette from various parties nongovernment. One of these is the free smoke home program (RBAR) already done in several areas in the city of Yogyakarta since 2009, until now has reached 137 RW, who has declared himself as RW RBAR. Until now, no research has proven influence of free smoke home program with smoking behaviour residents in the city of Yogyakarta. The purpose of this research to know the relationship between free smoke home programs with smoking behaviour in the city of Yogyakarta. Objective: Smoke Free Home Method: Quantitative research is analytic by approach of cross sectional. Sample is the head of families as active smokers, who living in RW RBAR and that live in RW non RBAR. The sample techniques used is cluster random sampling. Smoking behaviour is includes the number of cigarette which is inhaled every day Research. Result: p-value of the number of cigarette which is inhaled every day is 0.956 . Conclusion: there was no correlation between programs of free smoke with the number of cigarette which is inhaled every day.

Keywords: program of smoke-free home, smoking behavior, total consumption of cigarette
\end{abstract}

\section{INTRODUCTION}

Indonesia's health development goals stated in law No.36 of 2009 are to increase awareness, ability, and the willingness to live a healthy life for each population to realize the highest health status. To accomplish the goals of health development, that is if all components of the community are empowered and fully participate with the resources they have in implementing Clean and Healthy Behavior (PHBS). One element of PHBS is smoking behavior (1).

Riskesdas in 2010 also reported that nationally, the number of cigarettes smoked every day as many as 1-10 cigarettes were $52.3 \%$ of the population, and $41.0 \%$ were 11-20 cigarettes per day. Yogyakarta is one of the 4 provinces that have an average of 1-10 cigarettes smoking a day, with a rate of $66.3 \%$, and the number of smokers of $11-20$ cigarettes per day as much as $30.2 \%$, while the previous highest-ranking province is Maluku (69.2\%), NTT (68.7\%), and Bali (67.8\%) (2).

Riskesdas 2010, showed that Yogyakarta Special Region Province (DIY) is one of the provinces with the highest number of smokers. The prevalence of smokers in DIY is $31.6 \%$ of smokers who smoke in, and as much as
$66.1 \%$ still smoke in the house. While the results of the achievement in 2011, which gave the lowest contribution and is still a health problem in general, is no smoking inside the house which only reached $46.67 \%$. Household smokers are dominated by the head of the household or husband. Family members who don't smoke but are exposed to secondhand smoke are called passive smokers. So most household members are passive smokers, who have more dangerous health risks than active smokers (3).

The Government of Yogyakarta Province has made a Decree of the Governor relating to efforts to prevent smoking, primarily to protect passive smokers, including the issuance of Perda No. 2 of 2017 concerning No-Smoking Areas as an effort to reduce the prevalence of smoking behavior in the city of Yogyakarta. In an attempt to realize the environment (air), the community, families, and healthy individuals. The community has supported with the declaration of the RW area of the Smoke-Free House (RBAR) which contains declaration items about not smoking inside the house, not smoking during community meetings / meetings, and not providing ashtrays, installing stickers Smoke-Free Homes (RBAR) in doorstep and not smoking in front of children and pregnant women, even outside the home (3). 
Quit Tobacco Indonesia (QTI) cooperates with the Yogyakarta Health Office in the context of pioneering a smoke-free home (RBAR) program in the neighborhood of the Yogyakarta City RW community. The first time implementing the RBAR program was in 2009. There were four test areas, including RW 6 Suryowijayan, RW 11 Mujamuju, RW 1 Gunung Ketur, and RW 4 Pakuncen.(4). This series of smoke-free activities begin with socialization about the dangers of cigarette smoke and the right of people to breathe healthy air. The results of this activity are expected to get an agreement from the community to declare their area as an RBAR area with points of a declaration submitted by the community and signed by the regional head. The results of a survey from QTI in 2009, stated that $70 \%$ of men who smoke are willing to not smoke in the house if there are written regulations about it and approved by their regional leaders. The items agreed upon by the community will be the rules that must obey (5).

\section{METHOD}

Quantitative research is analytic with the cross-sectional approach. The sample of the study is the head of the family who is active smokers totaling 301 people. The sampling technique uses random cluster sampling. Measurement of the number of cigarettes smoked per day by residents using a questionnaire. The analytical method used is chi-square. Ethical clearance for this research was obtained from the research ethics committee of Ahmad Dahlan University, Indonesia (Letter of Ethical Approval, Number 011807107).Appropriate ethical conduct was maintained throughout the study.

\section{RESULTS AND DISCUSSION}

\section{Results}

The selected research areas in the RW area of Yogyakarta City are Smoke-Free Home, namely 5 RW, 10 $\mathrm{RT}$, and 70 households while the selected research areas in the non-smoking area (RBAR) city of Yogyakarta are 7 RW, $21 \mathrm{RT}$, and $231 \mathrm{KK}$.

1. The relationship Between the Smoke-Free Home (RBAR) Program and the Number of Cigarettes Smoked Per Day in the City of Yogyakarta.
Table 1. The Smoke-Free House Program with the number of cigarettes smoked every day by residents in the Yogyakarta City area.

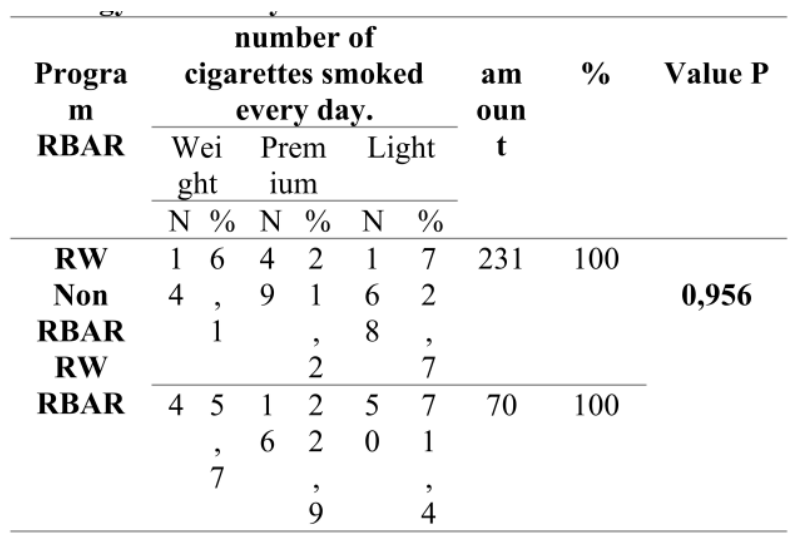

Table 1 shows that in the majority of RW Non RBAR there are $168(72.7 \%)$ heads of 231 households of active smokers who are included in the category of light smokers with the number of cigarettes smoked that is $<15$ cigarettes per day while those in the heavy smoker category are 14 $(6.1 \%)$ head of the family. Then for RW RBAR, there were $4(5.7 \%)$ heads of households from 70 families of active smokers who were included in the category of heavy smokers with the number of cigarettes smoked> 25 cigarettes per day, and as many as $50(71.4 \%)$ heads family included in the category of light smokers. According to the statistical test results in table 1 , it is obtained that the pvalue is 0.956 , which means that the value is less than 0.05 then $\mathrm{Ho}$ is accepted. This means it can be concluded that there is no significant relationship between the smoke-free home program with the number of cigarettes smoked every day.

\section{Disscussion}

Relationship of the RBAR Program with the Number of Cigarettes consumed Every day by Residents in the RW Region of Yogyakarta City.

The high prevalence of smokers in Indonesia is inseparable from a variety of determinants for the emergence of smoking. Through the Social Cognitive Theory framework, it is stated that health behavior is influenced by personal factors and environmental factors, which include the immediate environment (immediate environment) and the far environment (wider social context)(6). In the context of health campaigns, encouraging SCT methods to be used more comprehensively to address not only changes in individual behavior but also addressing sociostructural issues that surround the target audience that may be an inhibiting behavior change (7). The city of Yogyakarta has implemented the Smoke-Free Home program in several RW areas that have been willing to declare themselves as an effort from environmental factors, which are expected to be 
a solution to solving the smoking behavior of citizens, to protect family members as passive smokers from the dangers of cigarette smoke and help change behavior smoking the active smoker itself. The results of the study show that the Smoke-Free House (RBAR) program has no relationship with the number of cigarettes consumed by citizens every day, it is known that the $p$-value is 0.85 or $\alpha>0.05$. This is supported by the results of other studies, namely, that there is no relationship between smoking bans at work and employee smoking intensity. Many factors can cause a decrease in the number of cigarettes smoked every day. So it takes great motivation to stop smoking in adult smokers to be able to reduce their smoking habits (8).

In both sexes, smoking 1-4 cigarettes per day was significantly associated with higher risk of dying from ischaemic heart disease and from all causes, and from lung cancer in women. Accordingly, five cigarettes per day is not a threshold value for daily cigarette consumption that must be exceeded before serious health consequences occur (9). There was no association of sex, age, area of residence, SIMD, number of cigarettes smoked per day or pack-years with the probability of giving up smoking. The only variable associated with giving up smoking was the number of yearsa subject had smoked at baseline; people who had smoked the longest were slightly less likely to give up throughout the whole trial period (OR 0.99, 95\% CI 0.985$0.994, \mathrm{P}=0.012)(10)$.

Other findings also reinforce the theory that the influence of cognition or knowledge about smoking plays an important role in decreasing smoking behavior. More important than using drugs to reduce smoking addiction. In addition to cognition, it was also found that the risk for smoking was also reduced in men who have a partner and vice versa, the risk is increased in couples who are separated/divorced (11). During 2005-2016, the prevalence of cigarette smoking among U.S. adults declined from $20.9 \%$ to $15.5 \%$, and the proportion of ever smokers who had quit increased.

However, during 2015-2016, cigarette smoking prevalence did not change significantly. In 2016, 37.8 million U.S. adults were current cigarette smokers, and marked sociodemographic differences in smoking prevalence persist. Proven population-based interventions, including tobacco price increases, comprehensive smoke-free laws, anti-tobacco mass media campaigns, and barrier-free access to tobacco cessation counseling and medications, are critical to reduce cigarette smoking and smoking-related disease and death among U.S. adults, particularly among subpopulations with the highest prevalences (12). No significant signs and symptoms of secondhand smoking were found in children that lived with smoking family members as indicated by normal measurements of pulmonary function found in all respondents. However, more than half of these respondents were reporting subjective complaints of respiratory disturbances (13). The results showed that individuals' perceptions of smoking behavior and fears about the health consequences of passive smokers hold important influences related to social stigmatization (14). This social stigma is proven to be more effective than formal regulations governing the problem of smoking (15). That is why the slightest social environment starting from the neighbors, will be very influential.

Social assaults on cigarette smoking have created strong antismoking sentiment among the public. This study examined the idea that the strong antismoking sentiment may discourage cigarette smoking by creating an unfavorable smoking climate in which smoking is socially rejected as a deviant behavior (16). The results of our study highlight differences between two post-secondary educational institutions with different tobacco control methods (smoking zones and non-smoking zones). It seems that smoking zones are more effective in terms of self-reported compliance and effectiveness. There was no difference in preference as participants preferred to keep the zone that was already implemented on their respective campus. Additionally, it seems that there is a greater presence of authorities policing smoking zones than non-smoking areas and this may be a contributing factor to the adherence of the zone (17). The data presented in this study provide the most recent and comprehensive indication of smoking care provision in Australian hospitals. The results suggest few inpatients receive recommended smoking care during their stay. Only one fifth of respondents reported the provision of 5 of the 10 recommended elements of smoking care to $80 \%$ or more of inpatients. The majority of hospitals appear to inform inpatients of hospital smoke-free site policies and record patient smoking status. However, few hospitals provide smoking care or monitoring that would support abstinence during an inpatient stay, address withdrawal symptoms or assist with a quit attempt (18).

At the community level, we found that the management company's investment in an appealing physical environment and related community amenities were appreciated by residents, and in turn, residents took pride in their community. However, while this investment was valued, it was not sufficient in ensuring compliance to a smoke-free policy. Couching the policy as only one part of a broader health and wellness initiative that residents embrace may prove useful. Additionally, there was variability in the socialmilieu of the sites and how residents understood theircommunity; however, the implications this had on the levelof compliance is unclear. Further exploration around factorssuch as social cohesion is warranted in future studies. Takentogether, our findings suggest that compliance with thesmoke-free policy requires enforcement along withtransparent communication, and opportunities for collectivestaff and resident input into policy implementation details (19) Smoke-free legislation can influence individual and collective smoking behaviour in public spaces within reshaped socio-cultural environments (20). National smokefree work-place legislation was associated with steadily reducing employee exposure to ETS in a 4-year follow-up. 
[3] Dinas Kesehatan Kota Yogyakarta. Profil Kesehatan Kota Yogyakarta [Internet]. Yogyakarta; $2013 \quad$ [cited 2018 Dec 15].

further among men in the 4-year follow-up, but among women it increased after the initial drop (21). In 2001, 83.3\% were favourable to a smoking ban in public places, such as pubs or restaurants, and this figure increased to over $90 \%$ after the ban came into force. This study confirms, therefore, that the support for smoke-free policies increased once the policies were introduced. Moreover, the study quantified the fall in cigarette sales since the ban came into force in Italy at around $8 \%$, confirming the decrease in the short run found in selected US states and in Ireland. The new smoke-free legislation seemed to affect women and the younger population more frequently, although the estimate for the young was based on a small number of subjects and hence had a wide confidence interval (22).

Smoke-free workplaces not only protect non-smokers from passive smoking but also encourage smokers to quit or reduce their consumption, reducing total cigarette consumption per employee by $29 \%$. If all workplaces that are currently not smoke-free in the United States and the United Kingdom were to become smoke-free, consumption per capita (for the entire adult population) would drop by $4.5 \%$ and $7.6 \%$, respectively. Achieving the same result with a tax increase would require a $47 \%$ tax increase in the United States and a 24\% increase in the United Kingdom (23).

The overall results of this study suggest the effectiveness of the training program in changing knowledge about smoking hazards, attitudes towards smoking, and tobacco control and smoking cessation practices. It is encouraging that the trained Smoke-free Teens not only promoted smoke-free messages among their schoolmates, friends, and families, but also began to gather community support for a smoke free Hong Kong. The Smoke-free Teens Program has been instrumental in fostering a new batch of Smokefree Teens to advocate a smoke-free culture and protect the health of the public (24).

\section{CONCLUSION}

There is no relationship between the Cigarette Smoke (RBAR) program and the number of cigarettes smoked every day by residents in the RW area of Yogyakarta City, with the result $p$ value $=0.956$ or $\alpha>0.05$.

\section{REFERENCES}

[1] Ministry of Health. Riset kesehatan dasar (Riskesdas). 2013.

[2] Badan Penelitian dan Pengembangan KesehatanKementerian RI. Riset Kesehatan Dasar. Jakarta; 2010.

[4] Indonesia Conference on Tobacco or Health. $2^{\text {nd }}$ Indonesia Conference on Tobacco or Health. In: Tobacco Control: Saves Young Generation, Saves the Nation [Internet]. Jakarta Indonesia; 2015 [cited 2018 Dec 15].

[5] Quit Tobacco Indonesia. Panduan Rumah Bebas Asap Rokok. In Yogyakarta: Fakultas Kedokteran UGM; 2013.

[6] Swastikawara S, ... YL-JS, 2018 undefined. Intervensi Perilaku Sadar Bahaya Rokok Melalui Humor dan Rational Based Message Appeals. ejournal.unitomo.ac.id [Internet]. [cited 2019 Oct 2]

[7] Bandura A. Self-Efficacy. Int Encycl Soc Behav Sci Second Ed. 2015;4(1994):504-8.

[8] Anggraini F, Larasati T, Majority AW-J, 2013 undefined. Hubungan Larangan Merokok Di Tempat Kerja Dan Tahapan Smoking Cessation Terhadap Intensitas Merokok Pada Kepala Keluarga DiKelurahan Labuhan Ratu. juke.kedokteran.unila.ac.id [Internet]. [cited 2019 Oct 2]

[9] Bjartveit K, Tverdal A. Health consequences of smoking 1-4 cigarettes per day. Tob Control. 2005;14(5):315-20.

[10]Fowkes FJI, Stewart MCW, Fowkes FGR, Amos A, Price JF. Scottish smoke-free legislation and trends in smoking cessation. Addiction. 2008;103(11):1888-95.

[11] Blittner M, Goldberg J, Therapy MM-B, 1978 undefined. Cognitive self-control factors in the reduction of smoking behavior. Elsevier [Internet]. [cited 2019 Oct 2]

[12]Lundgren J, Babiker AG, Neaton JD. Randomized Trial of Reduced-Nicotine Standards for Cigarettes.N Engl J Med. 2016;374(4):394.

[13]Emma SDJ, Maulana M. Characteristics of Children with Secondhand Smoking. Indones J Med Heal JJKKI [Internet]. 2017;8(2):118-23. 
[23]Fichtenberg CM, Glantz SA. Behaviour : Systematic Review Systematic Review. 2002;325 (June 2006).

[24] Chung OK, Li WHC, Ho KY, Kwong ACS, Lai VWY, Wang MP, et al. A descriptive study of a Smoke-free Teens Programme to promote smoke free culture in schools and the community in Hong Kong. BMC Public Health. 2019;19(1):1-9.

[16] Taylor P, Kim S, Shanahan J. Journal of Health Communication: International Perspectives Stigmatizing Smokers: Public Sentiment Toward Cigarette Smoking and Its Relationship to Smoking Behaviors Stigmatizing Smokers : Public SentimentToward Cigarette Smoking and Its Relationship. (October 2012):37-41.

[17]Fagan* M, Nagpal* T, Fitzgeorge L, Smith W, Rosaasen J, Prapavessis H. Smoking zones versus smoke-free zones on Canadian postsecondary campuses: Which zone is more effective, adhered to and preferred? Tob Prev Cessat.2019;5(April).

[18]Freund M, Campbell E, Paul C, Sakrouge R, Wiggers J. Smoking care provision in smokefree hospitals in Australia. Prev Med (Baltim). 2005;41(1):151-8.

[19] Anthony J, Goldman R, Rees VW, Frounfelker RL, Davine J, Keske RR, et al. Qualitative Assessment of Smoke-Free Policy Implementation in Low-Income Housing: Enhancing Resident Compliance. Am J Heal Promot. 2019;33(1):107-17.

[20] Ritchie D, Amos A, Martin C. Public places after smoke-free-A qualitative exploration of the changes in smoking behaviour. Heal Place [Internet]. 2010;16(3):461-9.

[21] Heloma A, Jaakkola MS. Four-year follow-up of smoke exposure, attitudes and smoking behaviour following enactment of Finland's national smokefree work-place law. Addiction. 2003;98(8):1111-7.

[22] Gallus S, Zuccaro P, Colombo P, Apolone G, Pacifici R, Garattini S, et al. Effects of new smoking regulations in Italy. Ann Oncol. 2006;17(2):346-7. 